\title{
ENANTIOSELECTIVE REDUCTION OF ACETYLDIMETHYLPHENYLSILANE: A SCREENING WITH THIRTY STRAINS OF MICROORGANISMS
}

\author{
Christoph Syldatk ${ }^{a+}$, Andrea Stoffregen ${ }^{a}$, Frank Wuttke ${ }^{b}$ \\ and Relnhold Tacke ${ }^{b+}$ \\ a Institute of Biochemistry and Biotechnology, \\ Technical University of Braunschweig,Konstantin-Uhde-Straße 5, \\ D-3300 Braunschweig, FRG \\ bInstitute of Inorganic and Analytical Chemistry, \\ Technical University of Braunschweig, Hagenring 30, \\ D-3300 Braunschweig, FRG
}

\begin{abstract}
SUMMARY
Thirty strains of microorganisms (bacteria, yeasts, fungi and green algae) were tested as resting free cells for their ability to transform acetyldimethylphenylsilane (1) enantioselectively into $(R)$-(1-hydroxyethy 1$)$ dimethylphenylsilane $[(R)-2]$. The biotransformations were monitored by GC (packed OV-17 column), and the enantiomeric purities of the products isolated were determined by HPLC (cellulose triacetate column, UV detection). All microorganisms tested were found to reduce 1 enantioselectively to give $(R)-2$. Under the test conditions used, the yeast Trigonops is variabilis (DSM 70714) was found to exhibif the highest specific activity $\left(1.5 \mathrm{mg}\right.$ product $\times \mathrm{g}$ cell wet mass ${ }^{-1} \times$ min $^{-1}$ ), whereas the highest enantioselectivities were observed for the bacteria Acinetobacter calcoaceticus (ATCC 31012) ( $>95 \%$ ee), Brevibacterium species (ATCC 21860) ( $90 \%$ ee) and Corynebacterium dioxydans (ATCC 21766) ( $>95 \%$ ee), the yeast Candida humicola (DSM 70067) (90\% ee), the fungus Cunninghamella elegans (ATCC 26269) (94\% ee), as well as the cyanobacterium Symechococcus leopoliens is $(94 \%$ ee). From the green algae tested, Chlamydomonas reinhardii showed the highest enantioselectivity ( $85 \% \mathrm{ee})$.
\end{abstract}

\section{INTRODUCTION}

There are many examples in the recent literature indicating the increasing importance of bioconversions as reaction steps in the synthesis of 
optically active organic compounds (Schneider, 1985; Tramper et al., 1985; Yamada and Shimizu, 1988). In 1983 it was shown for the first time that biotransformations can also be useful for preparing optically active organosilicon compounds (Tacke et al., 1983). Since then a variety of stereoselective bioconversions of organosilicon substrates has been studied (Tacke and Becker, 1987; Syldatk et al., 1988). One of these reactions is the enantioselective reduction of acetyldimethylphenylsilane (1) into (R)(1-hydroxyethyl)dimethylphenylsilane $[(R)-2]$ using resting free cells (Syldatk et al., 1987) or immobilized cells (Stoffregen et al., 1987) of the yeast Trigonopsis variabilis (DSM 70714). Using resting free cells of this microorganism, $(R)-2$ could be prepared on a preparative scale with an enantiomeric purity of $86 \%$ ee (Syldatk et al., 1987).
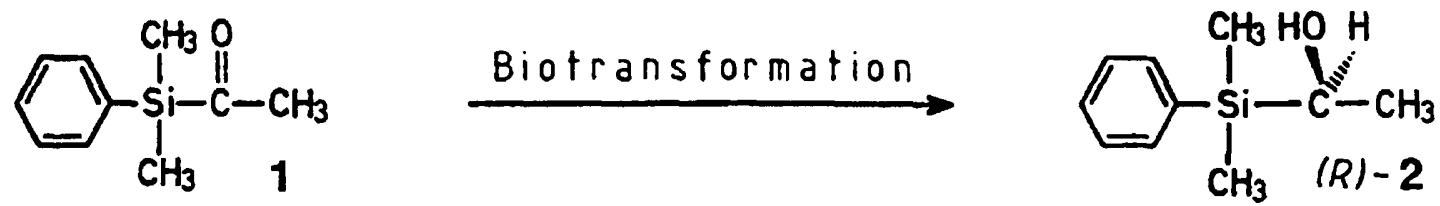

Here we report on the results of screening experiments with thirty different strains of microorganisms (see Table 1) which were tested for their ability to perform the conversion $1 \rightarrow(R)-2$. The aim of this study was (i) to improve the enantioselectivity of this biotransformation and (ii) to examine how far the ability is spread in biological systems to accept acetyldimethylphenylsilane (1) as a substrate for this reaction type. Compound 1 was regarded as a simple model substrate for acetylsilanes of the general type $R^{1} R^{2} R^{3} S i C(0) C H_{3}$.

\section{MATERIALS AND METHODS}

Substrate. Acetyldimethylphenylsilane (1) was synthesized according to the literature (Zilch and Tacke, 1986).

Microorganisms. All microorganisms listed in Table 1 were obtained from type culture collections (ATCC, DSM, IFO) and were cultivated in shake flasks at $100 \mathrm{rpm}$ under the conditions described in the respective catalogues. The cyanobacterium and the green algae were gifts from Professor Wettern (Institute of Botany, Technical University of Braunschweig, FRG).

Bioconversions. After cultivating the respective microorganisms (see above), the cell wet mass (CWM) was harvested at room temperature by 
centrifugation for 20 min at $6000 \mathrm{rpm}$ (Centrifuge 4121, Heraeus, Osterode, FRG). $1 \mathrm{~g}$ of the cell wet mass was suspended in $40 \mathrm{ml} 0.1 M$ Sorensen phosphate buffer, $\mathrm{pH} 6.8$, containing $800 \mathrm{mg}$ glucose, and was then incubated at $37^{\circ} \mathrm{C}$ and $100 \mathrm{rpm}$ in a $100 \mathrm{ml}$ Er lenmeyer flask. The bioconversion was started by addition of $10 \mathrm{mg}$ of the substrate 1 (substrate concentration: $\left.0.25 \mathrm{~g} \times \mathrm{l}^{-1}\right)$, and the reduction product 2 was isolated after complete conversion (GC control).

Monitoring of the bioconversions. At different times after starting the biotransformation, samples of $1 \mathrm{ml}$ of the culture broth were taken and subsequently extracted with $1 \mathrm{ml}$ of $n$-hexane. Quantitative determinations of 1 and 2 were performed by gas chromatographic analysis of $1 \mu 1$ of these extracts using a Packard gas chromatograph, model 428 [OV-17 column, 500 $\mathrm{mm}$; isothermal mode at $100^{\circ} \mathrm{C}$; carrier gas nitrogen; retention time: $2.6 \mathrm{~min}$ (1) and 3.2 min (2)].

Determination of the enantiomeric purities. After complete conversion of the substrate 1, the whole culture broth was extracted with $40 \mathrm{ml}$ of $n$ hexane. After removing the solvent of the organic extract under reduced pressure (rotary evaporator), the residue was dissolved in $0.3 \mathrm{ml}$ ethanol. $20 \mu 1$ of this solution were analyzed by HPLC (Beckman, model 338) on a cellulose triacetate column (No. 50003, Merck, Darmstadt, FRG) usjing ethanol $/ \mathrm{H}_{2} \mathrm{O}$ (bidest) $60: 40(\mathrm{~V} / \mathrm{V})$ as the eluent (flow rate: $0.8 \mathrm{ml} \times \mathrm{min}^{-1}$ ). The enantiomers of 2 were detected by UV at $254 \mathrm{~nm}$ (retention time: 79.9 $[(S)-2]$ and $104.1 \mathrm{~min}[(R)-2])$.

\section{RESULTS AND DISCUSSION}

Table 1 summarizes the results obtained in the screening experiments. All microorganisms tested were found to be able to reduce acetyldimethylphenylsilane (1) enantioselectively to give (R)-(1-hydroxyethyl)dimethylphenylsilane [(R)-2]. Large differences in specific activity (mg product $\times \mathrm{g}$ cell wet mass $\mathrm{m}^{-1} \mathrm{~min}^{-1}$ ) and in enantioselectivity (\% enantiomeric excess) were observed. Under the test conditions used, the yeast Trigonopsis variabilis (DSM 70714) exhibited the highest specific activity ( $1.5 \mathrm{mg}$ product $\times \mathrm{g}$ cell wet mass ${ }^{-1} \times \mathrm{min}^{-1}$ ), whereas the highest enantioselectivities (90 to $>95 \%$ ee) were found with the bacteria Acinetobacter calcoaceticus (ATCC 31012), Brevibacterium species (ATCC 21860) and Corynebacterium dioxydans (ATCC 21766), the yeast Candida humicola (DSM 70067), the fungus Cunninghamella elegans (ATCC 26269), as well as the cyanobacterium Synechococcus leopoliensis. From the green algae tested, the strain Chlamydomonas reinhardii exhibited the highest enantioselectivity ( $85 \% \mathrm{ee})$. 
Enantioselective reduction of acetyldimethylphenylsilane (1) into $(R)-(1-$ hydroxyethyl)dimethylphenylsilane $[(R)-2]$ : Specific activity of the biocatalysts and enantioselectivity of the bioconversions (reaction conditions: see experimental section)

\begin{tabular}{|c|c|c|c|c|}
\hline Microorganism & $\begin{array}{l}\text { Type } \\
\text { coll } \\
\text { and }\end{array}$ & $\begin{array}{l}\text { culture } \\
\text { lection } \\
\text { number }\end{array}$ & $\begin{array}{c}\text { Specific } \\
\text { activity } \\
(m g \text { product } x \\
\left.\text { g } \text { CWM }^{-1} \times \mathrm{min}^{-1}\right)\end{array}$ & $\begin{array}{l}\text { Enantio- } \\
\text { selectivity } \\
(\% \mathrm{ee})\end{array}$ \\
\hline $\begin{array}{l}\text { Acinetobacter calcoaceticus } \\
\text { Agrobacterium tumefaciens } \\
\text { Arthrobacter flavescens } \\
\text { Arthrobacter paraffineus } \\
\text { Arthrobacter species } \\
\text { Brevibacterium species } \\
\text { Corynebacterium dioxydans } \\
\text { Klebsiella oxycota } \\
\text { Nocardia species } \\
\text { Pseudomonas fluorescens } \\
\text { Rhodococcus erythropolis }\end{array}$ & $\begin{array}{l}\text { ATCC } \\
\text { IFO } \\
\text { ATCC } \\
\text { ATCC } \\
\text { DSM } \\
\text { ATCC } \\
\text { ATCC } \\
\text { ATCC } \\
\text { ATCC } \\
\text { ATCC } \\
\text { ATCC }\end{array}$ & $\begin{array}{l}31012 \\
3058 \\
13348 \\
15591 \\
3747 \\
21860 \\
21766 \\
8724 \\
4267 \\
15453 \\
11048\end{array}$ & $\begin{array}{l}0.31 \\
0.42 \\
0.67 \\
0.19 \\
0.31 \\
0.10 \\
0.31 \\
0.12 \\
0.76 \\
0.15 \\
0.49\end{array}$ & $\begin{array}{r}>95 \\
16 \\
64 \\
85 \\
75 \\
90 \\
>95 \\
63 \\
68 \\
70 \\
76\end{array}$ \\
\hline $\begin{array}{l}\text { Candida albicans } \\
\text { Candida boidinii } \\
\text { Candida humicola } \\
\text { Candida lipolytica } \\
\text { Candida utilis } \\
\text { Kloeckera corticis } \\
\text { Pichia guillermondii } \\
\text { Pichia pijperi } \\
\text { Torulopsis bombicola } \\
\text { Torulopsis candidum } \\
\text { Trigonopsis variabilis } \\
\text { Saccharomyces cerevisiae }\end{array}$ & $\begin{array}{l}\text { ATCC } \\
\text { DSM } \\
\text { DSM } \\
\text { DSM } \\
\text { DSM } \\
\text { ATCC } \\
\text { ATCC } \\
\text { ATCC } \\
\text { ATCC } \\
\text { DSM } \\
\text { DSM } \\
\text { ATCC }\end{array}$ & $\begin{array}{l}10231 \\
70026 \\
70067 \\
1345 \\
2361 \\
20108 \\
46036 \\
20129 \\
22214 \\
70590 \\
70714 \\
22224\end{array}$ & $\begin{array}{l}0.33 \\
0.28 \\
0.33 \\
0.33 \\
0.31 \\
0.24 \\
0.31 \\
0.35 \\
0.34 \\
0.28 \\
1.50 \\
0.32\end{array}$ & $\begin{array}{l}86 \\
32 \\
90 \\
21 \\
81 \\
80 \\
14 \\
10 \\
58 \\
36 \\
86 \\
78\end{array}$ \\
\hline $\begin{array}{l}\text { Aspergillus niger } \\
\text { Cunninghamella elegans } \\
\text { Geotrichum candidum } \\
\text { Ustilago maydis }\end{array}$ & $\begin{array}{l}\text { ATCC } \\
\text { ATCC } \\
\text { DSM } \\
\text { ATCC }\end{array}$ & $\begin{array}{l}9020 \\
26269 \\
1240 \\
14826\end{array}$ & $\begin{array}{l}0.05 \\
0.08 \\
0.32 \\
0.21\end{array}$ & $\begin{array}{l}77 \\
94 \\
58 \\
65\end{array}$ \\
\hline Synechococcus leopoliensis & SAG & $1402-1$ & 0.23 & 94 \\
\hline $\begin{array}{l}\text { Chlamydomonas reinhardii } \\
\text { Chlorella fusca }\end{array}$ & $\begin{array}{l}Y-1 \\
\text { SAG }\end{array}$ & $211 / 8 b$ & $\begin{array}{l}0.003 \\
0.67\end{array}$ & $\begin{array}{l}85 \\
75\end{array}$ \\
\hline
\end{tabular}

